\title{
Specific Binding of Substance P Aminoterminal Heptapeptide [SP(1-7)] to Mouse Brain and Spinal Cord Membranes
}

\author{
Orisa J. Igwe,' Duckhee C. Kim,, ${ }^{1}$ Virginia S. Seybold, ${ }^{2}$ Alice A. Larson' \\ University of Minnesota, College of Veterinary Medicine, Department of Veterinary Biology, St. Paul, Minnesota 55108, \\ and ${ }^{2}$ Department of Cell Biology and Neuroanatomy, University of Minnesota, College of Medicine, Minneapolis, \\ Minnesota 55455
}

\begin{abstract}
Aminoterminal fragments of substance $P$ (SP) have been previously shown to produce effects distinct, and often opposite, from those produced by the C-terminal of SP. The present investigation was initiated to determine whether $\mathrm{N}$-terminal fragments interact at binding sites distinct from the neurokinin-1 (NK-1) receptor where the C-terminal sequence of SP binds with high affinity, and distinct from $\mu$-opiate receptors, where we have previously shown the $\mathrm{N}$-terminal sequence of SP to interact. A tritium-labeled aminoterminal heptapeptide of SP, ${ }^{3} \mathrm{H}-\mathrm{SP}(1-7)$, was synthesized, purified, and used to characterize the binding of a variety of fragments of SP and opioids in the mouse brain and spinal cord membranes. Using the reduction of SP-induced caudally directed biting and scratching behaviors as an index of biological activity, ${ }^{3} \mathrm{H}-\mathrm{SP}(1-7)$ was shown to be equipotent to unlabeled SP(1-7). ${ }^{3} \mathrm{H}-\mathrm{SP}(1-7)$ was found to bind reversibly to a saturable population of sites. Scatchard analyses of concentration-dependent saturation of binding in the brain indicated a single population of noninteracting sites with a high affinity $\left(K_{d}=2.5 \mathrm{nM}\right)$ and a low capacity $\left(B_{\max }=29.2\right.$ $\mathrm{fmol} / \mathrm{mg}$ protein). Kinetic analyses indicated an apparent dissociation equilibrium constant of $2.1 \mathrm{~nm}$. Two populations of binding sites were observed in the spinal cord, one with a very high affinity $\left(K_{d}=0.03 \mathrm{~nm}\right)$ and low capacity $\left(B_{\max }=\right.$ $0.87 \mathrm{fmol} / \mathrm{mg}$ protein), and the other with lower affinity ( $K_{\alpha}$ $=5.4 \mathrm{nM})$ and intermediate capacity $\left(B_{\max }=19.6 \mathrm{fmol} / \mathrm{mg}\right.$ protein). Specific agonists for NK-1, NK-2, and NK-3 and $\delta$ opioid receptors, carboxyterminal tragments of SP, and a variety of other peptides did not compete at the ${ }^{3} \mathrm{H}-\mathrm{SP}(1-7)$ binding sites, but structurally related $\mathrm{N}$-terminal peptides

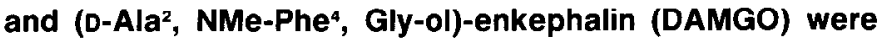
active in displacing the ligand. The binding site for ${ }^{3} \mathrm{H}-\mathrm{SP}(1-$ 7) appeared to be a membrane-bound complex whose specific binding was dependent on the integrity of both proteins and phospholipids. These studies are the first to characterize the binding sites for the SP $\mathrm{N}$-terminal partial sequence of SP that can be generated by metabolism in vivo. The expanding body of evidence for distinct biological activities of $\mathrm{N}$-terminal metabolites of SP, together with the current
\end{abstract}

\footnotetext{
Received Apr. 5, 1990; revised June 19, 1990; accepted July 3, 1990.

This work was supported by U.S. Public Health Service Grants NIDA 04090 , NIDA 04190 , and NIDA 00124.

Correspondence should be addressed to Orisa John Igwe, University of Minnesota, College of Veterinary Medicine, Department of Veterinary Biology, 1988 Fitch Avenue, 295 Animal Science/Veterinary Medicine Building, St. Paul, MN 55108.

Copyright (C) 1990 Society for Neuroscience $0270-6474 / 90 / 113653-11 \$ 03.00 / 0$
}

characterization of $\mathrm{N}$-terminal binding, strongly support the existence of an $\mathrm{N}$-terminal-directed SP receptor. The characteristics of SP(1-7) binding sites are consistent with those expected for an SP $\mathrm{N}$-terminal receptor.

Substance $\mathrm{P}(\mathrm{SP})$ is an undecapeptide that acts as a neurotransmitter or modulator in the mammalian PNS and CNS (Pernow, 1983). SP belongs to a family of neuropeptides called tachykinins, defined by their common C-terminal amino acid sequence, Phe- $X$-Gly-Leu-Met- $\mathrm{NH}_{2}$, where $X$ is either an alipathic (Val, Ile) or an aromatic (Phe, Tyr) residue (Erspamer, 1981). Three tachykinins, known as neurokinins, have been identified in the mammalian CNS: SP, neurokinin A (NKA), and neurokinin B (NKB) (Kanagawa et al., 1983; Kimura et al., 1983). Mammalian tachykinin receptors have recently been reclassified as NK-1, NK-2, and NK-3 receptor subtypes, based on whether their putative endogenous ligand is SP, NKA, or NKB, respectively (Burcher and Chahl, 1988; Regoli et al., 1988).

After exogenous administration or secretion from nerve terminals, the actions of SP are assumed to be terminated by diffusion from nerve endings, active reuptake into nerve endings, or enzymatic catabolism. Metabolism appears to be the primary mechanism for terminating the action of SP (Matsas et al., 1984; Mauborgne el al., 1986), as an active reuptake mechanism has only been reported for the C-terminal heptapeptide SP(5-11), but not for intact SP (Nakata et al., 1981). Several membranebound peptidases of CNS origin are reported to be involved in the metabolism of SP. A metal-chelator-sensitive endopeptidase from the human brain [EC 3.4.24-, (substance P-degrading enzyme)] has been shown to cleave SP between $\mathrm{Gln}^{6}-\mathrm{Phe}^{7}, \mathrm{Phe}^{7}-$ $\mathrm{Phe}^{8}$, and $\mathrm{Phe}^{8}-\mathrm{Gly}^{y}$ bonds (Lee et al., 1981), while a phosphoramidon-sensitive neutral endopeptidase [EC 3.4.24.11 ("enkephalinase" or endopcptidasc 24.11)] hydrolyzes SP at the Gln ${ }^{6}-\mathrm{Phe}^{7}, \mathrm{Phe}^{7}-\mathrm{Phe}^{8}$, and Gly ${ }^{9}-\mathrm{Leu}^{10}$ bonds (Matsas et al., 1984). Another substance P-degrading endopeptidase from the rat brain, shown to exhibit an inhibitor susceptibility distinct from that of endopeptidase 24.11, cleaves SP at Pro ${ }^{4}-\mathrm{Gln}^{5}, \mathrm{Gln}^{5}-\mathrm{Gln}^{6}$, and Gln ${ }^{6}-\mathrm{Phe}^{7}$ bonds (Endo et al., 1988), and an uncharacterized "bacitracin-sensitive" endopeptidase also hydrolyzes SP (Horsthemke et al., 1984). Brain angiotensin-converting enzyme (ACE) (EC 3.4.15.1) cleaves SP at the Phe ${ }^{8}-$ Gly $^{9}$ and Gly ${ }^{9}-\mathrm{Leu}^{10}$ bonds through its endopeptidase action (Yokosawa et al., 1983; Strittmatter et al., 1985). Therefore, the products of SP catabolism are primarily aminoterminal metabolites in both rats (Orloff et al., 1986) and mice (Igwe et al., 1990a).

Extensive structure-activity studies have shown that the receptor-mediated responsiveness of SP and other neurokinins 
appears largely encoded in the C-termini of the molecules (Holzer, 1988). Most of the biological effects of SP, such as its action on smooth muscles and its powerful central pressor effects, are attributed to its C-terminal tachykinin segment (Erspamer, 1981; Traczyk and Kubicki, 1981; Fuxe et al., 1982).

Not all the effects of centrally administered SP are mediated by its $\mathrm{C}$-terminal sequence. The $\mathrm{N}$-terminal fragments of SP have not only been shown to decrease SP-induced biting and scratching (B \& S) behaviors in mice in a dose-dependent manner (Sakurada et al., 1988; Igwe et al., 1990b), but their accumulation in vivo has been correlated with desensitization to SPinduced B \& S behaviors (Igwe et al., 1990a). The N-terminal heptapeptide SP(1-7) has been shown to be active in several behavioral paradigms when given intrathecally or intraperitoneally (Hall and Stewart, 1983, 1984; Gaffori et al., 1984; Pelleymounter et al., 1986). Using a microdialysis technique in freely moving rats, $S P(1-7)$ was also shown to inhibit the release of excitatory amino acids into the spinal-cord extracellular fluid, an effect opposite that of the C-terminal heptapeptide SP(5-11) (Skilling et al., 1990). It is not clear from available studies whether SP is enzymatically cleaved to the "active" fragment prior to NK-1-receptor activation or whether SP N-terminal fragments and intact SP act via the same receptor. While specific receptors for the $\mathrm{N}$-terminal partial sequences of SP have been proposed to exist in the mouse spinal cord and the rat salivary gland (Piercey et al., 1985), these receptors have not been characterized. Attempts at discriminating potential subsets of neuronal NK-1 receptors have been hindered by the unavailability of appropriate SP N-terminal-directed radioligands. Ligands typically used to study $\mathrm{NK}-1$ receptor-binding sites either are labeled on the N-terminal (e.g., with the bulky Bolton-Hunter reagent to give ${ }^{125}(-\mathrm{BHSP})$, which precludes its participation in the interaction or produces high background (e.g., ${ }^{3} \mathrm{H}-\mathrm{SP}$ ). Selective receptor ligands are ncccssary bccausc a single neurotransmitter acting on 2 or more different receptors can elicit a variety of different and sometimes opposite effects in complex tissue and in whole animals. In addition, selective agonists are important for basic studies of the mechanism by which a peptide produces its effects.

The present study was designed to test the hypothesis that $\mathrm{N}$-terminal metabolites of SP interact with distinct and biologically important receptors that specifically account for the pharmacological and physiological effects elicited by the $\mathrm{N}$-terminal partial sequences of SP. Experiments were therefore designed to determine the kinetics, specificity, and biochemical milieu required for ${ }^{3} \mathrm{H}-\mathrm{SP}(1-7)$ binding in fresh mouse brain and spinalcord membranes. The effects of SP-related peptides and specific opiate-receptor agonists on the SP N-terminal-sequence binding were also examined.

\section{Materials and Methods}

Animals. Male Swiss Webster mice (15-20 gm body weight; Biolab, White Bear Lake, MN) were used. Animals were maintained 4 per cage, had free access to food and water, and were acclimatized to the holding area for at least $24 \mathrm{hr}$ before use.

Chemicals. Synthetic SP, SP(1-4), SP(1-6), SP(1-7), SP(1-9), SP(311), SP(5-11), [Sar $\left.{ }^{9}, \operatorname{Met}\left(\mathrm{O}_{2}\right)^{11}\right] \mathrm{SP},\left[p-\mathrm{Glu}^{6}, \mathrm{Pro}^{9}\right] \mathrm{SP}(6-11)$ (Septide), [Pro ${ }^{7}$ neurokinin $\mathrm{B}$, [Nle $\left.{ }^{10}\right]$ neurokinin $\mathrm{A}(4-10)$, somatostatin,

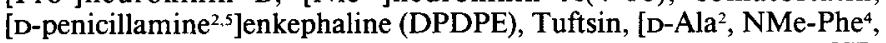
Gly-ol]enkephalin (DAMGO), [D-Arg ${ }^{1}$, D-Phe $^{5}$, D-Trp $^{7.9}$, Leu ${ }^{11}$ ]SP, phosphoramidon, chymostatin, and leupeptin were purchased from Peninsula Laboratories, Inc. (Belmont, CA). [D-Pro ${ }^{2}$, D-Phe] $\mathrm{SP}(1-7)$ and $\left[D-P_{0}^{2}, D-T r p^{7}\right] S P(1-7)$ were gifts from Dr. John M. Stcwart (Den- ver, $\mathrm{CO}$ ), and sufentanil citrate was a gift from Janssen Pharmaceutical. Stock solutions $\left(10^{-3} \mathrm{M}\right)$ of these compounds were made in doubledistilled water and stored frozen in aliquots until used. Thawed aliquots were used once and discarded. Tris $\mathrm{HCl}$, BSA, EDTA, urea, phospholipase $\mathrm{A}_{2}\left(\mathrm{PLA}_{2}\right)$ from Streptomyces violaceoruber, phospholipase D (Type VI) (PLD) from Streptomyces chromofuscus, trypsin, $\alpha$-chymotrypsin, dithiothreitol (DTT), chymotrypsin-trypsin inhibitor (CTI), sodium fluoride, sodium azide, Triton $\mathrm{X}-100$, polyethylenimine, parahydroxymercurobenzyolsulfonate ( $p$-HMBS), and ninhydrin spray were obtained from Sigma Chemical Co. (St. Louis, MO). Phospholipase C (Grade II) (PLC) from Bacillus cereus and concanavalin A from jack bean Canavalia ensiformis specific for $\alpha$-D-mannose $>\alpha$-D-glucose $>$ $\alpha$-D-GlcNAc were purchased from Boehringer Mannheim (Indianapolis, IN). Soybean agglutinin (A grade, Glycine soja specific for $N$-acetylgalactosaminyl and galactosyl residues) was purchased from Calbiochemicals (San Diego, CA), and $\beta$-funaltrexamine $\mathrm{HCl}(\beta$-FNA) and naloxonazine (Nalz) were purchased from Research Biochemical, Inc. (Natick, MA). Materials for thin-layer chromatography (TLC) were obtained from cither Aldrich or Fisher Chemical companies.

Synthesis, purification, and characterization of $\left[\right.$ prolyl $\left.{ }^{2.4} 3,4(\mathrm{n})^{3} \mathrm{H}\right] \mathrm{SP}(1-$ 7) or ${ }^{3} \mathrm{H}-\mathrm{SP}(1-7)$. The precursor for ${ }^{3} \mathrm{H}-\mathrm{SP}(1-7)$, [dehydroPro $\left.^{2,4} 3,4(n)\right]$ SP(1-7) (or Arg $^{1}-\Delta$ Pro $^{2}-$ Lys $^{3}-\Delta$ Pro $^{4}-$ Gln $^{5}-$ Gln $^{6}-$ Phe $^{7}$ ), was synthesized by the solid-phase method using Boc amino acids at the University of Minnesota Microchemical Facility. It was purified by high-performance liquid chromatography (HPLC) to greater than $95 \%$ purity and showed the expected amino acid ratio upon hydrolysis and amino acid analysis. ${ }^{3} \mathrm{H}-\mathrm{SP}(1-7)$ was prepared by a catalytic reduction (or hydrogenation) of the unsaturated precursor with tritium gas (Tritium Labelling Service, Amersham International). The catalyst and labile tritium were removed, and the crude ${ }^{3} \mathrm{H}-\mathrm{SP}(1-7)$ was received dissolved in absolute ethanol.

For purification, ethanol was removed in vacuo, before the crude product was fractionated on a reversed-phase HPLC using a $\mathrm{C}_{18}$ Ultrasphere ODS column with sodium dihydrogen phosphate $(\mathrm{pH}, 3.0)$ buffer/acetonitrile gradient system as described previously (Igwe et al., 1988). The peak corresponding to standard SP(1-7) was collected and taken to dryness in vacuo. Unlabeled SP(1-7) $(0.1 \mu \mathrm{g} / \mathrm{ml})$ with established retention in our HPLC gradient system was mixed with purified aliquots of ${ }^{3} \mathrm{H}-\mathrm{SP}(1-7)$ dissolved in $\mathrm{NaH}_{2} \mathrm{PO}_{4}$ buffer $(\mathrm{pH}, 3.0)$. To confirm that the unlabeled $\mathrm{SP}(1-7)$ and ${ }^{3} \mathrm{H}-\mathrm{SP}(1-7)$ exhibited identical chromatographic properties, an aliquot of the mixture was separated by HPLC. The eluant was sent through a Beckman 171 flow-through radiodetector (Beckman Instruments, Fullerton, CA) at a flow rate of 1 $\mathrm{ml} / \mathrm{min}$ and mixed with Ready Flow III ${ }^{\circledR}$ liquid-scintillation cocktail (Beckman) at a flow rate of $5 \mathrm{ml} / \mathrm{min}$. Analytical conditions for the HPLC were the same as previously described (Igwe et al., 1988). By intcrfacing the UV detcctor of the HPLC with the UV analogue tracing capability of the radiodetector with time-offset corrections determined automatically, the signals generated by both the standard SP(1-7) and ${ }^{3} \mathrm{H}-\mathrm{SP}(1-7)$ were aligned. The peak of radioactivity with an elution volume corresponding to unlabeled SP(1-7) was symmetrical. Analytical HPLC futher confirmed that $>95 \%$ of the radioactivity eluted in the position of unlabeled SP(1-7).

The homogeneity of the product was further confirmed by TLC on Avicell $\mathrm{F}$ (cellulose) plates (Fisher) using the following solvent system in the indicated ratios: [ $n$-butanol (15):pyridine (15):acetic acid (3): water (12)]. Unlabeled SP(1-7) and ${ }^{3} \mathrm{H}-\mathrm{SP}(1-7)$ were spotted in series on the same plates, but run on the same or separate lanes each time. After TLC runs, plates were sprayed with ninhydrin and warmed on a hot plate for 5 min to locate ${ }^{3} \mathrm{H}-\mathrm{SP}(1-7)$ and unlabeled $\mathrm{SP}(1-7)$ spots. The main radioactive spot ran consistently in the middle of the solvent front and had the same $R_{f}$ value as the unlabeled SP(1-7).

The purity of the final product was $92-97 \%$ with a specific activity of $27.9 \mathrm{Ci} / \mathrm{mmol}$ based on quantitative HPLC and confirmed by a bioassay as previously described (Igwe et al., 1990b).

Storage of ${ }^{3} \mathrm{H}-\mathrm{SP}(1-7)$. Aliquots of ${ }^{3} \mathrm{H}-\mathrm{SP}(1-7)$ were stored dry at $-20^{\circ} \mathrm{C}$ in polypropylene tubes in an evacuated dessicator. Under these storage conditions, the tracer was stable for at least 4 months (rate of decomposition, $<5 \%$ ) as evaluated by HPLC, which in addition confirmed that the tracer was carrier free. For use in binding studies, samples were dissolved in Tris-HCl buffer $(50 \mathrm{mM} ; \mathrm{pH}, 7.4)$ to give a $1.0-\mu \mathrm{M}$ dilution. Dissolved samples (stored at $4^{\circ} \mathrm{C}$ ) were discarded after $2 \mathrm{~d}$ because decomposition exceeded $10 \%$.

Bioassay for ${ }^{3} \mathrm{H}-\mathrm{SP}(1-7)$. SP, administered intrathecally in mice or rats, causes an immediate dose-dependent behavioral syndrome char- 
acterized by reciprocal hindlimb scratching and caudally directed biting and licking (Hylden and Wilcox, 1981), which we have referred to as B \& $S$ behaviors. Intrathecal-SP-induced B \& $S$ behaviors are significantly decreased by concurrent administration of, or pretreatment with, $\mathrm{N}$-terminal partial sequences of SP (Sakurada et al., 1988; Igwe et al., 1990b). The magnitude of the decrease in SP-induced behaviors with N-terminal fragments of SP was used as an index of biological activity in evaluating the pharmacologic efficacy of ${ }^{3} \mathrm{H}-\mathrm{SP}(1-7)$ compared to the unlabeled SP(1-7). The number of B \& $S$ behaviors elicited by an equimolar dose (7.5 pmol/mouse) of SP or [ $\left.p-\mathrm{Glu}^{6}, \mathrm{Pro}^{9}\right] \mathrm{SP}(6-11)$ (Septide) alone or in combination with an equimolar dose $(50 \mathrm{pmol} / \mathrm{mouse})$ of ${ }^{3} \mathrm{H}-\mathrm{SP}(1-7)$ or unlabeled SP(1-7) was recorded for $3 \mathrm{~min}$ after intrathecal injection. The assay was carried out as previously described (Igwe et al., 1990b). Briefly, a lumbar puncture was performed using a 20-gauge needle directly connected to a microsyringe. The needle was inserted between spinal vertebrae L5 and L6.The dose was delivered in a vol of $5 \mu \mathrm{l} /$ mouse.

Membrane preparation. The mice were decapitated, and their brains were removed. The spinal cords were obtained by transecting the vertebral column at the level of the cauda equina and applying hydraulic pressure to the caudal opening of the spinal column with ice-cold saline contained in a syringe attached to an 18-gauge needle. For each set of experiments, 4 brains (minus cerebelli) or 10 spinal cords were pooled in 50-ml polypropylene tubes containing 10 vol ice-cold buffer A [50 mm Tris- $\mathrm{HCl}(\mathrm{pH}, 7.4)$ at $4^{\circ} \mathrm{C}$ and $5 \mathrm{~mm} \mathrm{KCl}$. The tissue was homogenized with a Polytron (Brinkman Instruments, Westerberg, NY) for 5 $\mathrm{sec}$ at a setting of 8 . The homogenate was centrifuged at $39,000 \times \mathrm{g}$ for 10 min at $4^{\circ} \mathrm{C}$, and the supernatant was discarded. The pellet was resuspended (using a Teflon-glass homogenizer) in 10 vol ice-cold buffer B [50 mM Tris $\mathrm{HCl}(\mathrm{pH}, 7.4), 150 \mathrm{~mm} \mathrm{KCl}$, and $10 \mathrm{~mm}$ EDTA], incubated on ice for $30 \mathrm{~min}$, and centrifuged. The pellet was washed again by resuspension in $10 \mathrm{vol}$ ice-cold buffer $\mathrm{C}$ [ $50 \mathrm{~mm}$ Tris $\mathrm{HCl}$; $\mathrm{pH}, 7.4$ ) and recentrifuged. At this juncture, in competition studies involving preincubation of membranes with $\beta$-FNA or Nalz, the pellet was resuspended and incubated for $20 \mathrm{~min}$ at room temperature in $50 \mathrm{~mm}$ Tris- $\mathrm{HCl}$ buffer ( $\mathrm{pH}, 7.4$; room temperature) containing $2 \mu \mathrm{M} \beta$-FNA or $0.1 \mu \mathrm{M} \mathrm{Nalz}$, then ice-cold buffer $\mathrm{C}$ was added before centrifugation. In all cases, however, the pellet was washed once more in buffer $\mathrm{C}$, repeating the same procedure as above betore finally being resuspended (10 vol) in ice-cold buffer C. This suspension was used for binding. Aliquots were removed for protein determination according to the bicinchoninic acid method (Smith et al., 1985) using BSA as a standard. Fresh tissue was prepared for each experiment.

Binding assay. The binding of ${ }^{3} \mathrm{H}-\mathrm{SP}(1-7)$ to mouse brain and spinalcord membranes was performed at room temperature for $60 \mathrm{~min}$ in 50 mM Tris $\mathrm{HCl}$ buffer (pH, 7.4) containing $0.01 \%$ BSA, $2 \mu \mathrm{g} / \mathrm{ml}$ chymostatin, $4 \mu \mathrm{g} / \mathrm{ml}$ leupeptin, and $4 \mu \mathrm{g} / \mathrm{ml}$ phosphoramidon. Incubation was performed in $12-\times 75-\mathrm{mm}$ conical-bottom polypropylene culture tubes (Sarstedt, Inc., Princeton, NJ) in a final vol of $1.0 \mathrm{ml}$ containing the assay buffer and ${ }^{3} \mathrm{H}-\mathrm{SP}(1-7)$ (concentration range, $0.001-25 \mathrm{~mm}$ ). Unlabeled $\mathrm{SP}(1-7)(20 \mu \mathrm{M})$ was used to determine nonspecific binding. In competition studies, ${ }^{3} \mathrm{H}-\mathrm{SP}(1-7)(2.5 \mathrm{nM})$ was incubated with varying concentrations $(0.001 \mathrm{nM}-10 \mu \mathrm{M})$ of the unlabeled competitor of interest. In all cases, the incubation was started by adding tissue suspension ( 250 $\mu l)$ to the preequilibrated mixture.

Incubations were carried out in quadruplicate. At the end of the incubation period, bound ${ }^{3} \mathrm{H}-\mathrm{SP}(1-7)$ was separated from free by rapid filtration under vacuum through Whatman $\mathrm{GF} / \mathrm{C}$. filters using a Brandel receptor-binding harvester with a precise volume-delivery timer (Brandel Biomedical R\&D Labs, Gaithersburg, MD). To minimize nonspecific binding, the filters were presoaked overnight at $4^{\circ} \mathrm{C}$ in $0.1 \%$ polyethylenimine and $0.02 \% \mathrm{BSA}$ in $50 \mathrm{~mm}$ Tris $\mathrm{HCl}(\mathrm{pH}, 7.4)$ buffer, followed by oven drying at $70^{\circ} \mathrm{C}$ for $10-12 \mathrm{hr}$. Before use, filters were wet on the filtration stage with the ice-cold washing buffer [ $50 \mathrm{~mm}$ Tris $\mathrm{HCl}(\mathrm{pH}$, 7.4) at $\left.4^{\circ} \mathrm{C}\right]$. The incubation tubes and filters were washed once with a total of $2.5 \mathrm{ml}$ washing buffer. The filtration procedure, including the washing step, did not exceed 20 sec.

The filter disks were carefully removed with forceps and placed in 7-ml polypropylene counting vials, then $5 \mathrm{ml}$ of Beckman Ready Protein $^{+}$scintillation cocktail was added and each vial was counted in a Beckman scintillation spectrometer (Model LS 3801) with a ${ }^{3} \mathrm{H}$ counting efficiency of $45 \%$.

Specific ${ }^{3} \mathrm{H}-\mathrm{SP}(1-7)$ binding was defined as the difference between total binding and nonspecific binding. Nonspecific binding was determined as the amount of the ligand bound in the presence of $20 \mu \mathrm{M}$ unlabeled SP(1-7). Unless otherwise indicated, binding is expressed as the amount of ligand specifically bound per $\mathrm{mg}$ membrane protein

Integrity of ${ }^{3} \mathrm{H}-S P(1-7)$ after exposure to cell membranes. The stability of the ligand in the incubation medium after exposure to the membranes was evaluated. ${ }^{3} \mathrm{H}-\mathrm{SP}(1-7)(2.5 \mathrm{nM})$ was incubated as described above at room temperature with $0.5 \mathrm{mg}$ membrane protein per tube. After 60 min, the incubation mixture was transferred to microfuge tubes and centrifuged for 1 min in a microcentrifuge. The supernatant containing the unbound or free ligand was transferred to a clean set of tubes. The bound radioligand was extracted from tissue pellets with $0.5 \mathrm{ml} 1 \mathrm{~N} \mathrm{HCl}$ per tube for $30 \mathrm{~min}$ at $60^{\circ} \mathrm{C}$, after which the tubes were centrifuged briefly. Supernatants or tissue extracts were pooled ( 3 tubes per assay) and evaporated in vacuo. The residues were dissolved in $0.5 \mathrm{ml} \mathrm{HPLC}$ buffer $\left(50 \mathrm{~mm} \mathrm{NaH} \mathrm{PO}_{4} ; \mathrm{pH}, 3.0\right)$ containing $1 \mu \mathrm{g}$ unlabeled $\mathrm{SP}(1-7)$ per $\mathrm{ml}$. Aliquots $(75 \mu \mathrm{l})$ of the dissolved residues were subjected to HPLC analysis on a reversed-phase column interfaced with a Reckman 171 flow-through radiodetector as described above. ${ }^{3} \mathrm{H}-\mathrm{SP}(1-7)$ was automatically quantified in cpm. The unlabeled SP(1-7) was used to confirm the identity of the radioligand because both exhibited identical chromatographic properties.

Analysis of binding data. The data from competition studies with the ligand were analyzed by the computer program EBDA (McPherson, 1983), from which the inhibitory concentrations $\left(\mathrm{IC}_{50}\right)$ and the dissociation constants for the competitors $\left(K_{i}\right)$ were determined.On the basis of the raw data from the ligand-binding studies in mouse brain and spinalcord membranes, the EBDA program was used to process the data into a form that could be further analyzed by the nonlinear curve-fitting program LIGAND (Munson and Rodbard, 1980). LIGAND was used for calculating binding parameters $K_{d}$ and $B_{\max }$.

Statistical analyses of data were carried out by 1-way analysis of variance (ANOVA), followed by Scheffe's $F$ test of multiple comparisons, using a commercial computer software (Statview ${ }^{\circledR}$ ). All values are given as mean $\pm \mathrm{SEM}$.

\section{Results}

\section{Bioassay for ${ }^{3} \mathrm{H}-\mathrm{SP}(1-7)$}

Intrathecal coadministration of standard SP(1-7) or the radioligand with equimolar concentration of SP or Septide, a selective agonist at the NK-1 receptor, significantly decreased SP- and Septide-induced B \& S behaviors by approximately $50 \%$ for SP and $22 \%$ for Septide compared to either of these peptides alone (Fig. 1). The injection of the vehicle alone or with unlabeled or labeled SP(1-7) elicited no overt sign of reaction, escape, or B $\& \mathrm{~S}$ behaviors. These observations indicate that the observed B \& S behaviors were, in fact, elicited by SP and Septide and not by the injection per se. As an index of biological activity, this assay demonstrated that ${ }^{3} \mathrm{H}-\mathrm{SP}(1-7)$ was equipotent with unlabeled SP(1-7) and of equal efficacy in decreasing the B \& S behaviors induced by either SP or Septide. This assay also served to confirm that the tritiated material with chromatographic properties identical to unlabeled SP(1-7) produccd the same biological activities as the unlabeled $\mathrm{SP}(1-7)$ and therefore was ${ }^{3} \mathrm{H}-\mathrm{SP}(1-7)$.

\section{Binding kinetics}

Examination of the temperature dependence of the ligand binding in both brain and spinal-cord membranes showed that, with incubation at $4^{\circ} \mathrm{C}$, total and nonspecific binding were indistinguishable at the very low concentrations of the ligand $(0.001-$ $0.1 \mathrm{nM}$ ). In addition, the overall total binding at $4^{\circ} \mathrm{C}$ was lower than at room temperature over the ligand-concentration range (0.01-30 nM) studied, and the time to reach equilibrium was also longer ( $80 \mathrm{~min}$ ). All incubations were therefore carried out at room temperature.

The specific binding of the ligand as a function of brain membrane-protein concentration was linear up to $0.7 \mathrm{mg} / \mathrm{ml}$ (Fig. 2). A concentration of between 0.4 and $0.7 \mathrm{mg}$ protein per 


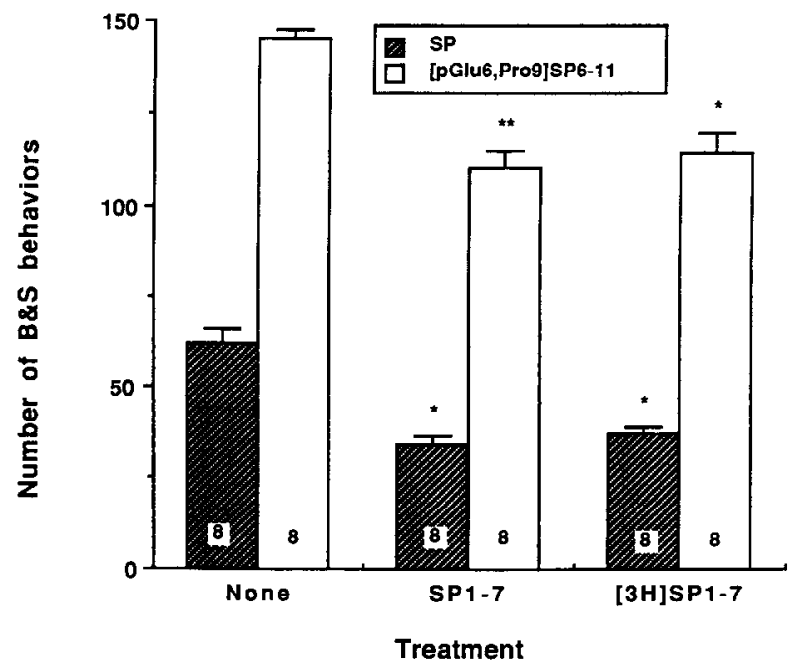

Figure 1. Histogram showing effect of standard $\mathrm{SP}(1-7)$ or ${ }^{3} \mathrm{H}-\mathrm{SP}(1-$ 7) on B \& $S$ behaviors elicited by SP and $\left[p-\mathrm{Glu}^{6}\right.$, Pro $] \mathrm{SP}(6-11)$ (Septide). An equimolar dose of SP or Septide $(7.5 \mathrm{pmol} / \mathrm{mouse})$ was administered intrathecally alone or in combination with $50 \mathrm{pmol}$ of either unlabeled $\mathrm{SP}(1-7)$ or ${ }^{3} \mathrm{H}-\mathrm{SP}(1-7)$ in a single injection. The intensity of the hehavioral response was measured for $3 \mathrm{~min}(0-3 \mathrm{~min})$ immediately following injection. Each bar represents the mean \pm SEM value from 2 independent experiments per group, with the total number of animals indicated at the base of the columns. For comparisons between SP or Septide alone or in combination with unlabeled SP(1-7) or ${ }^{3} \mathrm{H}-\mathrm{SP}(1-7)$, $F_{5,18}=138.9, p=0.0001$. $^{* *}, p \leq 0.01 ;{ }^{*}, p \leq 0.05$ (Scheffe's $F$ test of multiple comparisons).

incubation tube was routinely used in the experiments reported here because this concentration range gave good ratios of specific to nonspecific binding.

Binding of ${ }^{3} \mathrm{H}-\mathrm{SP}(1-7)(2.5 \mathrm{nM})$ to mouse-brain membranes as a function of incubation time is illustrated in Figures 3 and 4. Binding of the ligand reached an equilibrium at $40 \mathrm{~min}$ (Fig. 3 ) and was reversible (Fig. 4). Nonspecific binding remained constant throughout and did not exceed $20 \%$ of the total binding. Because bound SP(1-7) did not exceed $5 \%$ of the total ${ }^{3} \mathrm{H}-\mathrm{SP}(1-$ 7) at a 2.5-nM ligand concentration, and because virtually no degradation of the peptide was observed in the incubation medium after exposure to the membranes (see below), it was

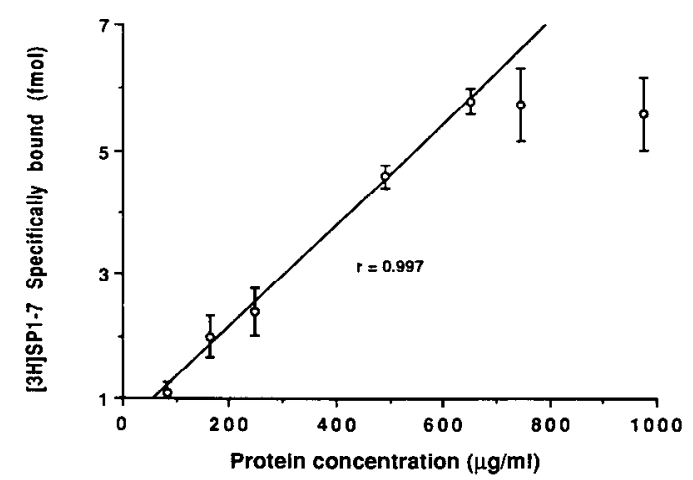

Figure 2. Binding of ${ }^{3} \mathrm{H}-\mathrm{SP}(1-7)(2.5 \mathrm{~nm})$ as function of mouse-brain membrane-protein concentrations. Specific binding was measured after $60 \mathrm{~min}$ incubation at room temperature as described in Materials and Methods. Binding is expressed as the amount of ${ }^{3} \mathrm{H}-\mathrm{SP}(1-7)$ specifically bound per $\mathrm{ml}$ of incubation medium. Each data point is the mcan \pm SEM of 4 separate experiments in quadruplicate. The correlation coefficient $r$ is for the first 5 data points, which lie within the protein concentration used in all experiments.

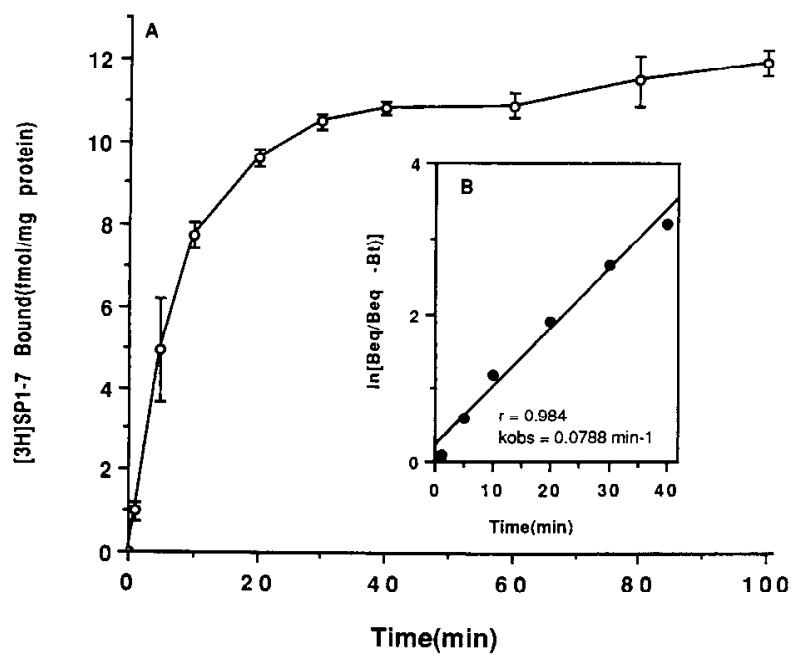

Figure 3. Time course of association of ${ }^{3} \mathrm{H}-\mathrm{SP}(1-7)$ to mouse-brain membranes. $A,{ }^{3} \mathrm{H}-\mathrm{SP}(1-7)(2.5 \mathrm{nM})$ was incubated at room temperature with mouse-brain membranes. Specific and nonspecific binding were measured at the times indicated. The samples were filtered and the filter disks counted for radioactivity as described in Materials and Methods. Each data point is the mean \pm SEM of 3 experiments in triplicate. The inset, $B$, is the analysis of the kinetics of association of ${ }^{3} \mathrm{H}-\mathrm{SP}(1-7)$ binding. Specific binding data from $A$ were linearized by plotting $\ln \left[B_{\mathrm{eq}} /\right.$ $\left(B_{\text {eq }}-B_{t}\right)$ ] versus time, where $B_{\text {eq }}=$ bound at equilibrium, and $B_{t}=$ bound at time $t$.

assumed that the concentration of free ligand in the medium remained constant with time. Therefore, the interaction of SP(17) with mouse-brain membranes was analyzed as a pseudo-firstorder reaction (Kitabgi et al., 1977). A plot of $\ln \left[B_{\mathrm{eq}} /\left(B_{\mathrm{eq}}-B_{t}\right)\right]$ (where $B_{\text {eq }}=$ binding at equilibrium, and $B_{t}=$ binding at time $t$ ) versus time for association was linear and yielded an apparent association rate, or $k_{\mathrm{obs}}$, of $0.0788 \mathrm{~min}^{-1}$ (Fig. $3 B$ ). The plot of $\ln \left[B_{t} / B_{\text {eq }}\right]$ versus time for dissociation also produced a straight line, indicating the expected first-order kinetics with a slope of $-0.0359 \mathrm{~min}^{-1}$, which corresponds to the dissociation rate constant of binding, or $k_{2}$ (Fig. $4 B$ ), with a $t_{1 / 2}$ of dissociation of $19.3 \mathrm{~min}$. From $k_{\mathrm{obs}}$ and $k_{2}$ values, the association rate constant, $k_{1}$, and the kinetically derived equilibrium dissociation constant, $K_{D}$, were calculated using the following equations:

$$
\begin{aligned}
k_{1} & =\left(k_{\text {obs }}-k_{2}\right) /[\text { ligand concentration }] \\
& =(0.0788-0.0359) /\left[2.5 \times 10^{-9} \mathrm{M}\right] \\
& =0.01716 \times 10^{9} \mathrm{M}^{-1} \mathrm{~min}^{-1}, \\
K_{D} & =k_{2} / k_{1} \\
& =0.0359 \mathrm{~min}^{-1} / 0.01716 \times 10^{9} \mathrm{M}^{-1} \mathrm{~min}^{-1} \\
& =2.1 \times 10^{-9} \mathrm{M}(\text { or } 2.1 \mathrm{nM}) .
\end{aligned}
$$

An equilibrium dissociation constant of $2.1 \mathrm{nM}$ is in good agreement with that determined from saturation data (see below).

\section{Number and affinity of binding sites}

The concentration dependence of SP(1-7) binding al equilibrium was determined in the presence of increasing concentrations of ${ }^{3} \mathrm{H}-\mathrm{SP}(1-7)$. To determine the number and affinity of the binding sites, mouse brain and spinal-cord membranes were incubated with ${ }^{3} \mathrm{H}-\mathrm{SP}(1-7)$ in the absence or presence of $20 \mu \mathrm{M}$ unlabeled SP(1-7) (Figs. 5, 6). Specific binding was found to be saturable with the ligand concentration in the 2 preparations of membranes. Scatchard analysis of the brain-membrane data 


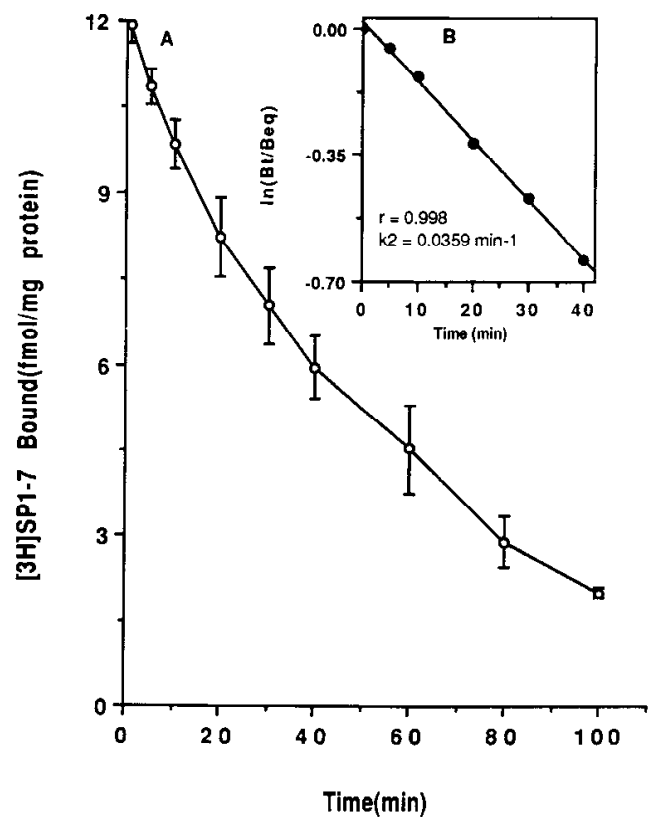

Figure 4. Time course of dissociation of ${ }^{3} \mathrm{H}-\mathrm{SP}(1-7)$ binding. $A,{ }^{3} \mathrm{H}-$ $\mathrm{SP}(1-7)(2.5 \mathrm{nM})$ was incubated at room temperature with mouse-brain membranes. After $100 \mathrm{~min}$ incubation, $20 \mu \mathrm{M}$ unlabeled $\mathrm{SP}(1-7)$ was added in a negligible volume (less than $1 \%$ of total incubation volume). Specifically bound ${ }^{3} \mathrm{H}-\mathrm{SP}(1-7)$ was measured by filtration at the times indicated after the addition of unlabeled $\operatorname{SP}(1-7)(t=0 \mathrm{~min}$ in figure), as described in Materials and Methods. The nonspecific binding, which has been subtracted from each experimental point, was determined throughout in a simultaneous experiment where unlabeled SP(1-7) at $20 \mu \mathrm{M}$ was added to the incubation medium at the beginning of the first incubation period. Each data point is the mean \pm SEM of 3 separate experiments conducted in triplicate. The inset, $B$, shows the analysis of the kinetics of dissociation of ${ }^{3} \mathrm{H}-\mathrm{SP}(1-7)$ from mouse-brain membranes. Dissociation data from $A$ were plotted as $\ln \left[B_{t} / B_{\text {eq }}\right]$ versus time, where $B_{\mathrm{eq}}=$ bound at equilibrium, and $B_{t}=$ bound at time $t$, assuming that reassociation of ${ }^{3} \mathrm{H}-\mathrm{SP}(1-7)$ with the membranes was inhibited by the excess of unlabeled SP(1-7).

gave a straight line (Fig. 5B), indicating that $\mathrm{SP}(1-7)$ binds to a single population of siles. The dissociation constant $\left(K_{d}\right)$ calculated from the data was $2.5 \mathrm{nM}$, which agrees reasonably well with that ( $2.1 \mathrm{nM})$ determined from the association and dissociation rate constants. A $B_{\max }$ value of $29.2 \mathrm{fmol}$ binding sites per $\mathrm{mg}$ protein was obtained from the brain data. A Hill plot generated from the labeled SP(1-7) was monophasic and showed no indication of cooperativity of the ligand binding sites in the mouse brain (Hill coefficient $=1.04 \pm 0.01, n=10$ ).

For the spinal-cord membranes, a Scatchard transformation (Fig. 6, inset) produced a concave curve, indicating a higher binding affinity at lower ligand concentrations. Analyses of the Scatchard plot, assuming 2 independent classes of sites, gave an estimate of 1 site with $K_{d}=0.03 \mathrm{nM}$ and $B_{\max }=0.87 \mathrm{fmol}$ binding site per mg protein (Fig. 6, inset portion $A$ ) and of another site with $K_{d}=5.4 \mathrm{nM}$ and $B_{\max }=19.6 \mathrm{fmol}$ binding sites per mg protein (Fig. 6, inset portion $B$ ).

\section{Nature of free and bound ligand recovered after incubation with membranes}

No significant degradation of the ligand was observed when the stability of the peptide was tested in the incubation medium after exposure to brain membranes under the conditions used in the binding assay (Fig. 7B). Upon HPLC analysis, 90-94\% of the radioactivity recovered in the supernatant eluted as intact

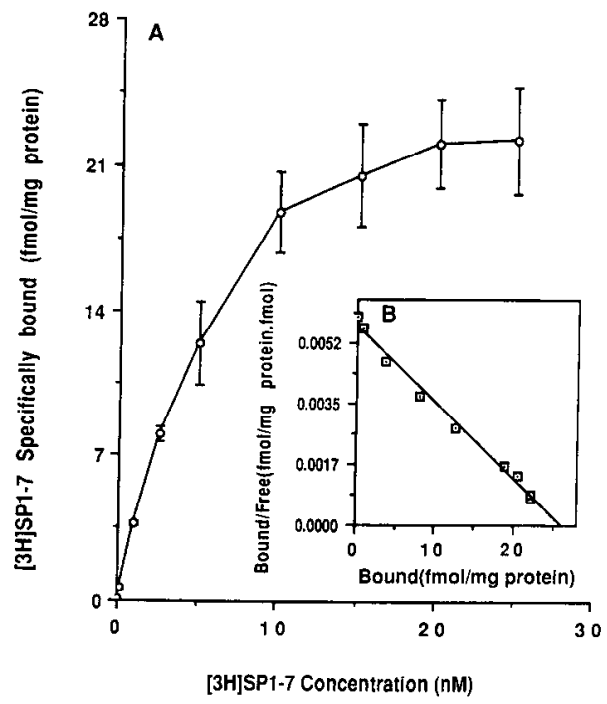

Figure 5. Saturation binding isotherms of ${ }^{3} \mathrm{H}-\mathrm{SP}(1-7)$ on mouse-brain membranes. $A$, Binding assays were performed with incrcasing concentrations of ${ }^{3} \mathrm{H}-\mathrm{SP}(1-7)$ in the absence (total binding) or presence (nonspecific binding) of $20 \mu \mathrm{M}$ unlabeled SP(1-7). Each data point represents the mean \pm SEM of 10 independent experiments performed in quadruplicate. The inset, $B$, shows a Scatchard plot of the data in $A$ with $K_{d}=$ $2.5 \pm 0.2 \mathrm{nM}$, and $B_{\max }=29.2 \pm 3 \mathrm{fmol} / \mathrm{mg}$ protein

${ }^{3} \mathrm{H}-\mathrm{SP}(1-7)$ compared to $97 \%$ for the control (unexposed) ligand (Fig. $7 A$ ). Tissue-bound ligand also showed no appreciable degradation (Fig. $7 \mathrm{C}$ ). The radioactivity derived from the incubation medium and that bound to tissue but extractcd with hydrochloric acid $\left(1 N\right.$ at $60^{\circ} \mathrm{C}$ for $\left.30 \mathrm{~min}\right)$ showed identical chromatographic profile as unlabeled $\mathrm{SP}(1-7)$ used as a carrier (Fig. $7 D$ ). This demonstrates that, during incubation, bound radioactivity did not undergo chemical or enzymatic modification.

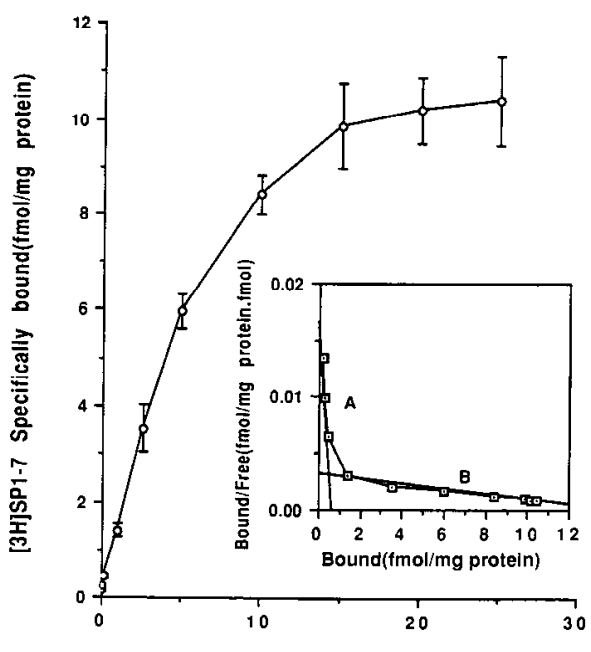

[3H]SP1-7 Concentration (nM)

Figure 6. Saturation-binding isotherms of ${ }^{3} \mathrm{H}-\mathrm{SP}(1-7)$ on mouse spinal-cord membranes. Binding assays were performed with increasing concentrations of ${ }^{3} \mathrm{H}-\mathrm{SP}(1-7)$ in the absence (total binding) or presence (nonspecific binding) of $20 \mu \mathrm{M}$ unlabeled SP(1-7). Each data point is the mean \pm SEM of 6 independent experiments performed in quadruplicate. The inset shows a Scatchard transformation of the binding data. A concave curve is indicated. $A$, Scatchard analysis produced a curve with $K_{d}=0.03 \pm 0.005 \mathrm{nM}$, and $B_{\max }=0.87 \pm 0.2 \mathrm{fmol} / \mathrm{mg}$ protein. $B$, Scatchard analysis produced a curve with $K_{d}=5.4 \pm 0.64 \mathrm{nM}$, and $B_{\max }$ $=19.6 \pm 2.7 \mathrm{fmol} / \mathrm{mg}$ protein. 
Figure 7. Stability of ${ }^{3} \mathrm{H}-\mathrm{SP}(1-7)$ during incubation with mouse-brain membranes. ${ }^{3} \mathrm{H}-\mathrm{SP}(1-7)(2.5 \mathrm{nM})$ was incubated under the conditions of the binding assay. After $1 \mathrm{hr}$, the incubation mixture was centrifuged, and the supernatant containing free or unbound ${ }^{3} \mathrm{H}-\mathrm{SP}(1-7)$ was removed and saved. The tissue residue with bound ${ }^{3} \mathrm{H}-\mathrm{SP}(1-7)$ was extracted with $1 \mathrm{~N} \mathrm{HCl}$ at $60^{\circ} \mathrm{C}$ for $30 \mathrm{~min}$ and centrifuged again. The clear supernatants from both the initial incubation and the subsequent tissue extracts were evaporated to dryness in vacuo. Aliquots of the residues, dissolved in HPLC buffer, were mixed with carrier SP(1-7) and analyzed by HPLC with an on-line radiodetcetor as described in Materials and Methods. The arrows indicate retention times. $A$, unexposed ${ }^{3} \mathrm{H}-\mathrm{SP}(1-7) ; B$, free ${ }^{3} \mathrm{H}-\mathrm{SP}(1-$ 7); $C$, bound ${ }^{3} \mathrm{H}-\mathrm{SP}(1-7) ; D$, carrier $\mathrm{SP}(1-$ 7).

\section{Competitive inhibition of binding}

A variety of peptides and nonpeptides $(0.001 \mathrm{nM}-10 \mu \mathrm{M})$ were tested for their ability to inhibit competitively the binding of ${ }^{3} \mathrm{H}-\mathrm{SP}(1-7)$ to mouse-brain membranes (Table 1).

With N-terminal partial sequences of SP, the inhibition of SP(1-7) binding appears to depend partly on the length of the sequence. The aromatic amino acid $\mathrm{Phe}^{7}$ seems fundamental for specific binding because the relative affinities of the tetrapeptide $\mathrm{SP}(1-4)$ and the hexapeptide $\mathrm{SP}(1-6)$ are 0.2 and $0.5 \%$, respectively. The extension of the polypeptide sequence to the nonapeptide SP(1-9) or to the full SP sequence increased the relative affinities to only 16 and $9 \%$, respectively. The putative antagonist for SP, [D-Arg ${ }^{1}$, D-Phe ${ }^{5}, \mathrm{D}^{-T_{r} p^{7,9}}$, Leu $\left.{ }^{11}\right]$ SP (Tsou et al., 1985), has a relative affinity of only $2 \%$. In contrast, [D-Pro ${ }^{2}$, D-Phe $\left.{ }^{7}\right] \mathrm{SP}(1-7)$ and [D-Pro $\left.{ }^{2}, \mathrm{D}-\operatorname{Trp}^{7}\right] \mathrm{SP}(1-7)$, which are putative antagonists for SP(1-7) (J. Stewart, personal communication) and retain the aromaticity in position 7 , have affinities of 61 and $28 \%$, respectively, to that of $\operatorname{SP}(1-7)$.

The C-terminal sequences of SP [nonapeptide SP(3-11) and heptapeptide SP(5-11)], somatostatin, tuftsin, DPDPE [a potent $\delta$-opioid-receptor agonist (Mosberg et al., 1983)], [Nle $\left.{ }^{10}\right] \mathrm{NKA}(4-$ 10) [an NK-2 receptor-specific agonist (Drapeau et al., 1987)], and [Pro $\left.{ }^{7}\right] \mathrm{NKB}$ [an NK-3 receptor-specific agonist (Lavielle et al., 1988)] were all virtually inactive as competitors for ${ }^{3} \mathrm{H}-\mathrm{SP}(1-$ 7) binding at up to $10 \mu \mathrm{M}$ in each case. [Sar $\left.{ }^{9}, \operatorname{Met}\left(\mathrm{O}_{2}\right)^{11}\right] \mathrm{SP}$, an NK-1 receptor-specific agonist (Drapeau et al., 1987), had a relative affinity of $0.8 \%$ in competing for $\mathrm{SP}(1-7)$ binding sites. Although DAMGO, a $\mu$-opioid-specific agonist (Kosterlitz and Paterson, 1981), was very active with over $60 \%$ relative affinity, naloxone, a nonpeptide with a high affinity for the $\mu$-opioid
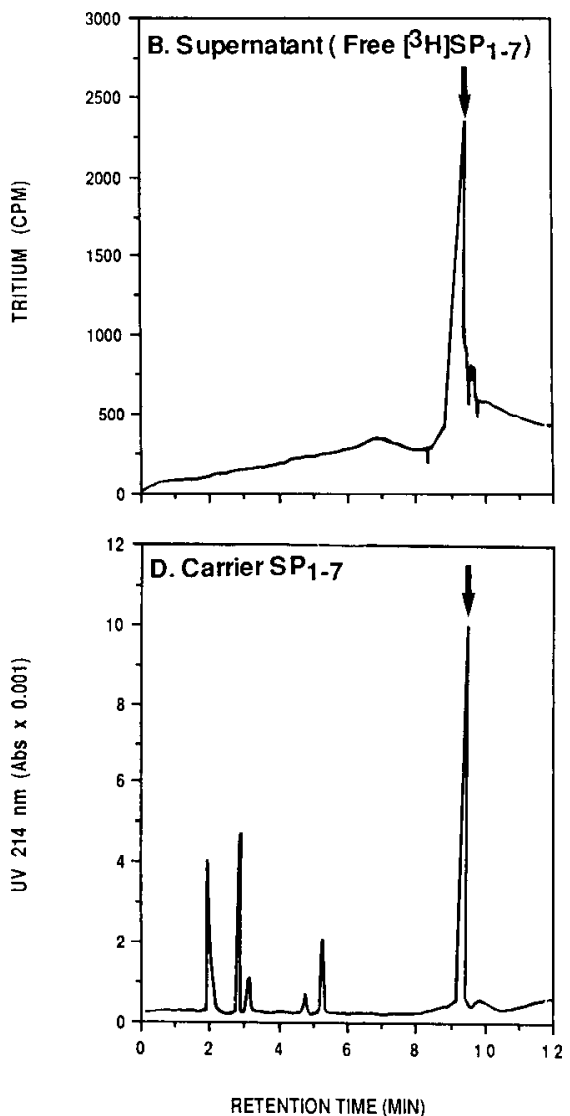

RETENTION TIME (MIN)

rcceptor comparcd to other opioid receptors, had a relative affinity of only $0.2 \%$. Sufentanil citrate [a selective nonpeptide $\mu$-opioid agonist (Leysen et al., 1983)] was virtually inactive as a competitor for ${ }^{3} \mathrm{H}-\mathrm{SP}(1-7)$ binding. Morphine sulfate, another selective nonpeptide $\mu$-opioid agonist, had a relative affinity of less than $2 \%$. Pretreatment of membranes with $\beta$-FNA $(2 \mu \mathrm{M}$ for $20 \mathrm{~min}$ at room temperature), the fumarate methyl ester of naltrexone shown to be a selective, irreversible inhibitor of the $\mu$-opioid receptor (Portoghese et al., 1980; Takemori et al., 1981), did not affect the relative affinity of DAMGO on SP(1 -7) binding compared to untreated membranes. In addition, preincubation of brain membranes with $\mathrm{Nalz}(0.1 \mu \mathrm{M}$ for $20 \mathrm{~min}$ at room temperature), a highly selective and apparently irreversible antagonist for the putative $\mu_{1}$-opioid receptor (Hahn and Pasternak, 1982; Johnson and Pasternak, 1984), did not affect the ability of DAMGO to compete for ${ }^{3} \mathrm{H}-\mathrm{SP}(1-7)$ binding relative to untrcatcd membrancs.

\section{Effects of reagents and enzymes on binding}

The influence of various reagents and enzymes on ${ }^{3} \mathrm{H}-\mathrm{SP}(1-7)$ binding to mouse-brain membranes was evaluated (Table 2 ) as a preliminary biochemical characterization of the properties of the binding sites for the N-terminal sequence of SP. Binding was abolished by the thiol-blocking reagent $p$-HMBS, an effect that was prevented by pre- or concurrent incubation with DTT, suggesting a role for sulfhydryl groups in the binding sites. DTT itself provided limited stimulation of binding.

${ }^{3} \mathrm{H}-\mathrm{SP}(1-7)$ binding was abolished by trypsin and $\alpha$-chymotrypsin, but restored by incubation with CTI, consistent with the binding site being a protein. Denaturing treatments such as urea $(0.5 \mathrm{M})$ or heat $\left(60^{\circ} \mathrm{C}\right)$ also eliminated binding, suggesting 
Table 1. Inhibition of ${ }^{3} \mathrm{H}-\mathrm{SP}(1-7)$ binding to mouse-brain membranes.

\begin{tabular}{|c|c|c|c|}
\hline Peptide/nonpeptide & $K_{i}(\mathrm{nM})^{a}$ & $\begin{array}{l}\text { Relative } \\
\text { affinity }^{b}\end{array}$ & $\mathrm{IC}_{50}(\mathrm{nM})^{a}$ \\
\hline $\operatorname{SP}(1-7)$ & $2.6 \pm 0.8$ & 100 & $5.4 \pm 1.3$ \\
\hline $\mathrm{SP}(1-4)$ & $1121 \pm 192^{* *}$ & 0.2 & $2196 \pm 576^{* *}$ \\
\hline $\mathrm{SP}(1-6)$ & $501 \pm 148^{* *}$ & 0.5 & $852 \pm 250^{* *}$ \\
\hline $\mathrm{SP}(1-9)$ & $17 \pm 4^{*}$ & 15 & $29 \pm 7^{*}$ \\
\hline $\mathrm{SP}$ & $28 \pm 6^{* * *}$ & 9 & $49 \pm 10^{* * *}$ \\
\hline$\left[\mathrm{D}-\mathrm{Arg}^{1}, \mathrm{D}-\mathrm{Phe}^{5}, \mathrm{D}-\operatorname{Trp}^{7,9}, \mathrm{Leu}^{\prime \prime}\right] \mathrm{SP}$ & $140 \pm 14^{* *}$ & 2 & $254 \pm 25^{* *}$ \\
\hline$S P(3-11)$ & $>10,000$ & 0.005 & $>10,000$ \\
\hline $\mathrm{SP}(5-11)$ & $>100,000$ & $<0.005$ & $\gg 100,000$ \\
\hline$\left[\operatorname{Sar}^{9}, \operatorname{Met}\left(\mathrm{O}_{2}\right)^{11}\right] \mathrm{SP}$ & $325 \pm 77^{* *}$ & 0.8 & $554 \pm 161^{* *}$ \\
\hline$\left[\mathrm{Nle}^{10}\right] \mathrm{NKA}(4-10)$ & $>100,000$ & $<0.005$ & $\gg 100,000$ \\
\hline$\left[\right.$ Pro $\left.^{7}\right] \mathrm{NKB}$ & $>100,000$ & $<0.005$ & $\gg 100,000$ \\
\hline DAMGO & $4.4 \pm 0.2^{*}$ & 59 & $7.5 \pm 0.4^{*}$ \\
\hline DPDPE & $\gg 100,000$ & $<0.005$ & $\gg 100,000$ \\
\hline$\left[\mathrm{D}-\mathrm{Pro}^{2}, \mathrm{D}-\mathrm{Phe}^{7}\right] \mathrm{SP}(1-7)$ & $4.2 \pm 0.5^{*}$ & 62 & $7.4 \pm 1.5^{*}$ \\
\hline$\left[\mathrm{D}-\mathrm{Pro}^{2}, \mathrm{D}-\mathrm{Trp}\right] \mathrm{SP}(1-7)$ & $9.4 \pm 1.5^{*}$ & 28 & $16 \pm 2.4^{*}$ \\
\hline Somatostatin & $>10,000$ & $<0.005$ & $>10,000$ \\
\hline Tuftsin & $>100,000$ & $<0.005$ & $\gg 100,000$ \\
\hline Naloxone $\mathrm{HCl}$ & $1337 \pm 380^{* *}$ & 0.2 & $2336 \pm 662^{* *}$ \\
\hline Sufentanil citrate & $>100,000$ & 0.002 & $\gg 100,000$ \\
\hline Morphine sulfate & $207 \pm 44^{* *}$ & 1.3 & $376 \pm 80^{* *}$ \\
\hline$\beta$-FNA/SP( $(1-7)$ & $2.6 \pm 0.6$ & 100 & $4.5 \pm 1.0$ \\
\hline$\beta$-FNA/DAMGO & $4.3 \pm 0.7^{*}$ & 60 & $7.5 \pm 1.2^{*}$ \\
\hline Nalz/SP(1-7) & $3.3 \pm 0.5$ & 100 & $5.9+0.9$ \\
\hline Nalz/DAMGO & $6.3 \pm 0.3^{*}$ & 53 & $11.3 \pm 0.5^{*}$ \\
\hline
\end{tabular}

Binding of ${ }^{3} \mathrm{H}-\mathrm{SP}(1-7)(2.5 \mathrm{~nm})$ was determined in the absence or in the presence of 8 different concentrations $(0.001$ $\mathrm{nM}-10 \mu \mathrm{M})$ of competing peptides/nonpeptides. The concentrations of the competing peptide or nonpeptide needed to cause $50 \%$ inhibition of specific binding $\left(\mathrm{IC}_{50}\right)$ and the apparent inhibition constant $K_{i}$ were calculated using the computer program EBDA (McPherson, 1983).

${ }^{a}$ Values for $K_{i}$ and $\mathrm{IC}_{50}$ are the mean \pm SEM of 3-4 independent experiments conducted in quadruplicate. For comparisons between and within different groups of interests, $\mathbf{F}_{2.6}=9.08, p=0.015 ; F_{2.7}=19.8, p=0.001 ; F_{5.13}=75.6, p<0.0001$. * The mean $K_{i}$ for each compound was used to calculate its affinity as a competitor relative to $\operatorname{SP}(1-7)$, that is, $\left[K_{t}\right.$ of $\mathrm{SP}(1-7) / K_{i}$ of competitor] $\times 100$.

$* p \leq 0.05$ (Sheffe's $F$ test of multiple comparisons).

** $p \leq 0.01$.

that high temperatures disrupt and destroy the complex tertiary structure of the receptor protein. EDTA, a metal-chelating reagent, and phosphoramidon, an endopeptidase 24.11 (EP-24.11) enzyme inhibitor, did not affect binding, indicating that the binding of ${ }^{3} \mathrm{H}-\mathrm{SP}(1-7)$ to EP-24.11 (whose specificity may happen to resemble that of a binding site) was not measurable at the concentrations used. Binding appeared relatively insensitive to bacterial preparations such as PLA $\mathrm{A}_{2}$ and PLC, but PLD drastically reduced it by $72 \%$. These results suggest that the polar moieties of phospholipids that are affected selectively by PLC and PLD may be required for binding. In addition, the effect of PLD and Triton X-100 at $1 \%$, but not at $0.1 \%$, further suggests that reduction in binding can be attributable to the degradation or disruption of a lipid component of the binding site. Soybean agglutinins completely abolished binding, while concanavalin $A$ reduced it drastically, evidence that the binding site for the $\mathrm{N}$-terminal sequence of SP is a glycoprotein containing $N$-acetylgalactosaminyl, galactosyl, and D-mannose residues, and, very likely, other sugars as well. This property may prove useful in attempts at receptor purification. The absence of any effect on binding by sodium azide and sodium fluoride suggests that the binding is not dependent on energy from oxidative metabolism or glycolysis, providing further evidence that the observed binding is other than active transport into a subcellular organelle.

\section{Discussion}

The present study demonstrates that an N-terminal partial sequence of SP, SP(1-7), binds to mouse brain and spinal-cord membranes. The binding is specific, saturable, and reversible. Binding also appears to be dependent on incubation time, temperature, and membrane-protein concentration. The affinity of $\mathrm{SP}(1-7)$ for its binding site in the brain is high, and the binding appears to involve only 1 type of site without cooperative interaction. In the spinal cord, however, the data suggest more than 1 class of binding sites. The radioligand used in our study elicits a physiological response comparable to unlabeled N-terminal metabolites of SP (Sakurada et al., 1988; Igwe et al., $1990 \mathrm{~b}$ ). Intrathecal coadministration of equimolar concentrations of either the unlabeled SP(1-7) or ${ }^{3} \mathrm{H}-\mathrm{SP}(1-7)$ with SP or its C-terminal-directed congener $\left[p-\mathrm{Glu}^{6}, \mathrm{Pro}^{9}\right] \mathrm{SP}(6-11)$ resulted in equipotent reductions in $\mathrm{B} \& \mathrm{~S}$ behaviors.

Two classes of analogues can be distinguished upon examination of the selective binding affinities of the partial sequences of SP: (1) Analogues with primarily the C-terminal region, such as nona-SP(3-11) and hepta-SP(5-11), are totally inactive in their ability to compete for ${ }^{3} \mathrm{H}-\mathrm{SP}(1-7)$ binding. Thus, the data suggest that the C-terminal sequences of SP that bind to (Hanley et al., 1980; Park et al., 1984), and are physiologically active at 


\begin{tabular}{|c|c|}
\hline Treatment $^{a}$ & $\begin{array}{l}{ }^{3} \mathrm{H}-\mathrm{SP}(1-7) \\
\text { binding } \\
(\% \text { control })^{b}\end{array}$ \\
\hline Trypsin (1 U) & 0 \\
\hline $\operatorname{Trypsin}(1 \mathrm{U})+$ CTI $(0.1 \mathrm{mg})$ & $87 \pm 12$ \\
\hline Urea $(0.5 \mathrm{M})$ & 0 \\
\hline Heat $\left(60^{\circ} \mathrm{C}, 40 \mathrm{~min}\right)$ & 0 \\
\hline$\alpha$-Chymotrypsin (1 U) & 0 \\
\hline$\alpha$-Chymotrypsin (1 U) + CTI $(0.1 \mathrm{mg})$ & $102 \pm 9$ \\
\hline $\mathrm{PLA}_{2},(2 \mathrm{U})$ & $98 \pm 4$ \\
\hline PLC (2 U) & $89 \pm 4$ \\
\hline PLD (2 U) & $18 \pm 0.3$ \\
\hline DTT (1 mM) & $145 \pm 17$ \\
\hline$p$-HMBS (1 mM) & 0 \\
\hline$p$-HMBS $(1 \mathrm{mM})+$ dithiothreitol $(2 \mathrm{mM})$ & $95 \pm 8$ \\
\hline Concanavalin $\mathrm{A}(1.25 \mathrm{mg})$ & $32 \pm 7$ \\
\hline Soybean lecithin $(1 \mathrm{mg})$ & 0 \\
\hline EDTA $(1 \mathrm{~mm})$ & $94 \pm 8$ \\
\hline Phosphoramidon (1 mM) & $103 \pm 4$ \\
\hline Sodium fluoride (1 mм) & $95 \pm 10$ \\
\hline Sodium azide ( $1 \mathrm{~mm})$ & $91 \pm 3$ \\
\hline Triton X-100 (1\%) & $38 \pm 6$ \\
\hline
\end{tabular}

Mouse-brain membranes, prepared as indicated in Materials and Methods, were suspended in ice-cold $50 \mathrm{~mm}$ Tris $\mathrm{HCl}(\mathrm{pH}, 7.4)$, and aliquots containing $0.5 \mathrm{mg}$ protein were incubated with reagents and enzymes as indicated. At the end of the incubation period, samples were rapidly filtered under vacuum through Whatman $\mathrm{GF} / \mathrm{C}$ filters using a Brandel harvester. Filters were washed once with ice-cold washing buffer and assayed for ${ }^{3} \mathrm{H}-\mathrm{SP}(1-7)$ binding (see Materials and Methods). "All incubations were carried out for $1 \mathrm{hr}$ at room temperature unless otherwise stated.

${ }^{b}$ All values are expressed as means \pm SEM of 3-4 independent experiments in triplicate for each treatment.

(Bury and Mashford, 1976; Jacques et al., 1989), the NK-1 receptor are not involved in SP N-terminal-sequence activity. (2) The N-terminal region of SP is 1 of the prerequisites for binding, as evidenced by increasing relative affinities with increasing fragment length. The pentapeptide $\mathrm{SP}(1-4)$ and the hexapeptide SP(1-6) were almost inactive. The relative affinity of the nonapeptide $\mathrm{SP}(1-9)$ increased to $16 \%$, then decreased to $9 \%$ with the full sequence of SP. The aromatic $\mathrm{Phe}^{7}$ is not only fundamental for specific binding, but also appears to be a transition amino acid for increased and/or diminished binding affinities. Thus, the relative affinity of SP(1-9) is 6 times less than that of SP(1-7), but 2 times greater than that of SP, which has a full complement of both $\mathrm{N}$ - and C-termini. Curiously, these relative affinities for the $\mathrm{SP}(1-7)$ binding site are not translated into pharmacological potencies because all the $\mathrm{N}$-terminal sequences studied were equipotent in reducing SP-induced B \& S behaviors during their concurrent intrathecal injection with $S P$. In multiple injections, however, $\operatorname{SP}(1-7)$ was more potent than SP(1-9) in the same bioassay (Igwe et al., 1990b). Based on the findings in this study and the known structure-activity relationships for tachykinin receptors, the binding sites for ${ }^{3} \mathrm{H}-\mathrm{SP}(1-$ 7) do not appear to involve NK-1, NK-2, or NK-3 receptors. The relative affinities of $\mathrm{N}$-terminal sequencies of $\mathrm{SP}$ cannot be explained exclusively on the basis of the presence of $\mathrm{N}$-terminal positively charged basic amino acids $\left(\mathrm{Arg}^{1}\right.$ and $\left.\mathrm{Lys}^{3}\right)$, as ${ }^{3} \mathrm{H}-$ $\mathrm{SP}(1-7)$ was poorly displaced by $\left[\mathrm{Sar}^{9}, \operatorname{Met}\left(\mathrm{O}_{2}\right)^{11}\right] \mathrm{SP}, \mathrm{SP}(1-4)$, or tuftsin (an immunoglobulin heavy-chain-associated tetrapeptide, Thr-Lys-Pro-Arg), which share sequence homology with SP(1-7) and possess a full complement of these basic amino acids at their N-terminal sequences. In contrast, DAMGO, which does not share basic amino acid homology with the $\mathrm{N}$-terminus of SP, competed well for ${ }^{3} \mathrm{H}-\mathrm{SP}(1-7)$ binding. Therefore, positively charged amino acids are not the only requirement for full activity at the $\mathrm{N}$-terminal binding site. This differentiates the binding sites described in the present investigation from those of the agonists displaying histamine-releasing activity from mast cells (Devillier et al., 1989).

The existence of SP(1-7) as a metabolite of SP in the CNS is supported by anatomical evidence. SP(1-7)-like immunoreactivity has been observed in the superficial laminae of the dorsal horn of the spinal cord and in the caudal part of the spinal trigeminal nucleus (Stewart et al., 1982). High concentrations of SP(1-7) exist in the dorsal horn of the lumbar spinal cord compared to the other regions of the CNS (Sakurada et al., 1985). In the straitonigral pathway, EP-24.11 specifically cleaves $\mathrm{SP}$ at the $\mathrm{Phe}^{7}-\mathrm{Phe}^{8}$ bond (Oblin et al., 1989). The presence of a material showing cross-reactivity to an antiserum against the human-brain EP-24.11 has been reported in the rat spinal cord (Probert and Hanley, 1987). In addition, the rat nucleus tractus solitaris is rich in both EP-24.11 and the SP(1-7) metabolite (Lasher et al., 1986). The localization of "SP-degrading enzyme" immunoreactivity in the rat spinal cord (Probert and Hanley, 1987) also closely parallels that of major SP-containing nervefiber systems (Barber et al., 1979; Gibson et al., 1981) and the occurrence of SP binding sites (Mantyh and Hunt, 1985).

The pharmacological activities of SP N-terminal partial sequences are firmly established. $\mathrm{SP}(1-7)$ is essentially devoid of activity in the guinea pig ileum (Chipkin et al., 1979), but is equipotent to SP in lowering mean arterial pressure and heart rate when administered into the nucleus of the solitary tract (I Iall et al., 1989). Administraton of phosphoramidon, a specific inhibitor of EP-24.11, reversibly blocked the depressor and bradycardic effects of SP, but not those of SP(1-7). In contrast, the C-terminal hexapeptide $\mathrm{SP}(5-11)$ elevates blood pressure and heart rate when injected intracerebroventricularly (Hall et al., 1987). The N-terminal heptapeptide $\mathrm{SP}(1-7)$ has also been shown to be active in several behavioral paradigms, such as attenuation of grooming and of isolation-induced fighting in mice (Hall and Stewart, 1983, 1984) and the facilitation of passive avoidance behavior (Gaffori et al., 1984; Pelleymounter et al., 1986). More recently, the N-terminal sequence of SP has been found to enhance inhibitory avoidance learning (Hasenöhrl et al., 1990).

Interestingly, the pharmacological effects of SP(1-7) are more potent in their ability to inhibit effects of SP than those elicited by the so-called SP antagonists such as [D-Pro $\left.{ }^{2}, \mathrm{D}-\mathrm{Trp}^{7.9}\right] \mathrm{SP}$ and [D-Arg ${ }^{1}$, D-Pro $^{2,4}$, D-Trp $^{7,9}$, Leu $\left.{ }^{11}\right]$ SP (Sakurada et al., 1987; Takahashi et al., 1987). It appears unlikely that N-terminal metabolites of SP are competitive antagonists against SP, because SP $(1-7)$ has very low affinity for the NK-1 receptor (Hanley et al., 1981). This low affinity is confirmed in the current study.

The precise locus of SP cleavage by EP-24.11 is unclear. SP(17) is unlikely to be produced and stored presynaptically, as the in vivo tissue concentrations of SP(1-7) are low compared to SP (Sakurada et al., 1985; Igwe et al., 1988), and the N-terminal metabolites of SP are not taken up again into nerve terminals (Segawa et al., 1978). SP(1-7) is most likely produced in the synaptic cleft following the synaptic release of SP. The B \& S behaviors elicited by SP administered intrathecally have been interpreted as a direct postsynaptic activation of the sensory pathways (i.e., NK-1 receptor activation; Hunskaar et al., 1986). 
We have demonstrated that concomitant intrathecal injection of SP and its $\mathrm{N}$-terminal fragments significantly reduced the number of behaviors elicited by SP alone (Igwe et al., 1990a), offering further evidence for postsynaptic production of SP(17). In the spinal cord and elsewhere, EP-24.11 is associated with synaptic membranes (Lasher et al., 1986), and SP(1-7) generated at the synapse would interact with the $\mathrm{N}$-terminal binding site before being further degraded by a variety of peptidases.

A number of studies suggest that $\mathrm{N}$-terminal fragments of SP may exert their effects via an interaction with opioid receptors. This suggestion is based on the ability of $\operatorname{SP}(1-7)$ to displace DAMGO at $\mu$ binding sites (Krumins et al., 1989), the attribution of SP-induced analgesia to met-enkephalin release (Naranjo et al., 1986), and the ability of high doses of naloxone to inhibit the development of desensitization to repeated injections of SP (Larson, 1988). In the present study, we have also shown that DAMGO is active in competing with $\mathrm{SP}(1-7)$ binding site (Table 1), further implicating $\mu$-opioid receptors in the binding of N-terminal metabolites of SP.

Much compelling evidence, however, argues against the binding site for the N-terminal metabolite of SP described in this report being an opioid receptor. Although DAMGO, a $\mu$-opioid receptor-specific agonist, competes well at the $\mathrm{SP}(1-7)$ binding site, pretreatment of membranes with $\beta$-FNA [a specific nonequilibrium (or irreversible) $\mu$-opioid antagonist (Porloghese et al., 1980)] did not alter the interaction of DAMGO at the N-terminal binding site for SP. Evidence that the binding site for $\mathrm{N}$-terminal sequence of SP is not a $\mu_{1}$-opiate receptor is provided by the inability of preincubation of brain membranes with Nalz to affect ${ }^{3} \mathrm{H}-\mathrm{SP}(1-7)$ binding in subsequent competition experiments with DAMGO relative to the controls (Table 2). Preincubation of membranes with Nalz has been shown to cause dramatic reductions in the binding of $\left.{ }^{3} \mathrm{H}-\mathrm{D}-\mathrm{Ala}^{2}, \mathrm{D}-\mathrm{Leu}^{5}\right]-$ enkephalin (or ${ }^{3} \mathrm{H}$-DADLE), a sclcctive $\delta$-opioid-receptor ligand, and ${ }^{3} \mathrm{H}-\mathrm{DAMGO}$, which possess high affinities for the $\mu_{1}$ binding site (Cruciani et al., 1987). DAMGO displaces ${ }^{3} \mathrm{H}$ DPDPE, another highly selective ligand for the $\delta$-opioid receptor (Mosberg et al., 1983), with extremely high affinity (Cotton et al., 1985). DPDPE did not compete with ${ }^{3} \mathrm{H}-\mathrm{SP}(1-7)$ for binding at all, but DAMGO did, with a relative affinity of $59 \%$, which is consistent with the uniqueness of the binding site for the $\mathrm{N}$-terminal sequence of SP, different from the $\mu$ or the putative $\mu_{1}$ site. In addition, sufentanil and naloxone, both with high affinities for the $\mu$-opioid receptor, did not compete with $\operatorname{SP}(1-$ 7). Naloxone was also found to have no effect on SP(1-7) isolation-induced aggression in mice, though it blocked the isolation-induced fighting elicited by SP and its C-terminal fragments (Hall and Stewart, 1984). Aminoterminal fragments of SP did not cause met-enkephalin release (Naranjo et al., 1986), and the depressor cffects mediated by SP(1-7) were still obtained in rats pretreated with naloxone (Hall et al., 1989). Taken together, the evidence suggests that the $\mathrm{N}$-terminal region acts by a different mechanism from the C-terminal region or the complete SP molecule. In addition, sulfhydryl reagents have been shown to inhibit specific opioid binding (Simon et al., 1973). We have shown in this study (Table 2) that DTT increased SP(1-7) binding, thus biochemically discriminating the binding site from an opiate receptor. The high relative affinity of DAMGO, however, remains a paradox, suggesting that DAMGO has 2 different receptor-interacting sites. The high affinity, $\beta$-FNA-insensitive DAMGO binding site that is sensitive to $\mathrm{N}$-terminal metabolites of SP may reflect a nonopioid receptor.
The results obtained with the N-terminal metabolites of SP strongly suggest that the binding occurs at sites that are analogous to those involved in some of the pharmacological and/or biological effects of the peptide (Hall and Stewart, 1983; Cridland and Henry, 1988). The ability of SP(1-7) to induce pharmacological and/or physiological responses comparable to SP in some cases, but opposite to those of its C-terminal sequences, clearly demonstrates that the $\mathrm{N}$-terminal sequence can be "recognized," thus suggesting the existence of a receptor for N-terminal metabolites of SP. Piercey et al. (1982) postulated 2 classes of $\mathrm{SP}$ receptors, $S P_{1}$ and $S P_{2}$, for receptors insensitive to or sensitive to, respectively, $\mathrm{N}$-terminal sequences. Our present data (Table 1), showing the relative affinities of $\mathrm{N}$ - and $\mathrm{C}$-terminal fragments of SP in brain membranes, support a related classification for the NK-1 receptor to which SP is an endogenous agonist (Burcher and Chahl, 1988). Because NK-2 and NK-3 receptor-specific agonists do not interact at the N-terminal binding site of SP, we propose that the aminoterminaldirected binding site be designated SP-N.

Our data showing a highly selective interaction of ${ }^{3} \mathrm{H}-\mathrm{SP}(1-$ 7) with a binding site that appears to be distinct from $\mu, \mu_{1}$, or NK-1 receptors suggest that a receptor is present in the CNS that could mediate the effects of SP N-terminal metabolites. These data support the hypothesis that, as a neurotransmitter for sensory neurons of the spinal cord, SP contributes to pain and elicits a variety of other effects by interaction of the C-terminal part of the molecule with the NK-1 receptor, while central receptors for SP in systems mediating other behavioral actions probably recognize the aminoterminal catabolic fragments. The present demonstration of a dissociation of SP action along both molecular and functional lines opens the way for development of agents with specificity of action in each system.

\section{References}

Barber RP, Vaughn JE, Slemmon JR, Salvaterra PM, Robets E, Leeman SE (1979) The origin, distribution and synaptic relationships of substance $P$ axons in rat spinal cord. J Comp Neurol 184:331-352.

Burcher E, Chahl LA (1988) Tools for tachykinin and neuropeptide research: a conference report. Neurosci Lett 86:38-44.

Bury R, Mashford M (1976) Biological activity of C-terminal partial sequences of substance P. J Med Chem 19:854-856.

Chipkin RE, Stewart JM, Sweeney VE, Harris K, Williams R (1979) In vitro activities of some synthetic substance $P$ analogs. Arch Int Pharmacodyn Ther 240:193-202.

Cotton R, Kosterlitz IIW, Paterson SJ, Rance MJ, Traymor JR (1985) The use of tritiated 2-D-penicillamine-5-D-penicillamine enkephalin as a highly selective ligand for the delta-binding site. Br J Pharmacol 84:927-932.

Cridland RA, Henry JL (1988) N- and C-terminal fragments of substance P: spinal effects in the rat tail flick test. Brain Res Bull 20:429432 .

Cruciani RA, Lutz RA, Munson PJ, Rodbard D (1987) Naloxonazine effects on the interaction of enkephalin analogs with mu-1, mu and delta opioid binding sites in rat brain membranes. J Pharmacol Exp Ther 242:15-20.

Devillier P, Drapeau G, Renoux M, Regoli D (1989) Role of the $\mathrm{N}$-terminal arginine in the histamine-releasing activity of substance $\mathrm{P}$, bradykinin and related peptides. Eur J Pharmacol 168:53-60.

Drapeau G, D'Orleans-Juste P, Dion S, Rhaleb NE, Rouissi NE, Regoli $D$ (1987) Selective agonists for substance $P$ and neurokinin receptors. Neuropeptides 10:43-54.

Endo S, Yokosawa H, Ishii S (1988) Purification and characterization of substance P-degrading endopeptidase from rat brain. J Biochem 104:999-1006.

Erspamer V (1981) The tachykinin peptide family. Trends Neurosci 4:267-269.

Fuxe K, Agnati L, Rosell S, Harfstrand A, Folkers K, Lundberg J, Andersson K, Hokfelt T (1982) Vasopressor effects of substance P 
and C-terminal sequences after intracisternal injection to $\alpha$-chloralose-anaesthetized rats: blockade by a substance $\mathbf{P}$ antagonist. Eur $\mathbf{J}$ Pharmacol 77:171-176.

Gaffori O, Stewart JM, deWied D (1984) Influence of SP and fragments on passive avoidance behavior. Experimentia 40:89-91.

Gibson SJ, Polak JM, Bloom SR, Wall PD (1981) The distribution of nine peptides in rat spinal cord with special emphasis on substantia gelatinosa and on the area around the central canal (lamina X). J Comp Neurol 201:65-79.

Hahn EF, Pasternak GW (1982) Naloxonazine, a potent, long acting inhibitor of opiate binding sites. Life Sci 31:1385-1388.

Hall ME, Stewart JM (1983) Substance P and behavior: opposite effects of N-terminal and C-terminal fragments. Peptides 4:763-768.

Hall ME, Stewart JM (1984) Modulation of isolation-induced fighting by $\mathrm{N}$ - and C-terminal analogs of substance $\mathrm{P}$ : evidence for multiple recognition sites. Peptides 5:85-89.

Hall ME, Miley FB, Stewart JM (1987) Modulation of blood pressure by substance $\mathrm{P}$ : opposite effects of $\mathrm{N}$ - and $\mathrm{C}$-terminal fragments in anesthetized rats. Life Sci 40:1909-1914.

Hall ME, Miley FB, Stewart JM (1989) The role of enzymatic processing in the biological actions of substance P. Peptides 10:895-901.

Hanley MR, Sandberg BEB, Lee CM, Iversen LL, Brundish DE, Wade $R$ (1980) Specific binding of ${ }^{3} \mathrm{H}$-substance $\mathrm{P}$ to rat brain membranes. Nature 286:810-812.

Hanley M, Lee C, Watson S, Sandberg B, Iversen L (1981) Biochemical and pharmacological studies of substance $P$ receptors. Protides Biol Fluids 29:477-482.

Hasenöhrl RU, Gerhardt P, Huston JP (1990) Substance P enhancement of inhibitory avoidance learning: mediation by the $\mathrm{N}$-terminal sequence. Peptides 11:163-167.

Holzer P (1988) Local effector functions of capsaicin-sensitive sensory nerve endings: involvement of tachykinins, calcitonin gene-related peptide and other neuropeptides. Neuroscience 24:738-768.

Horsthemke B, Schulz M, Bauer K (1984) Degradation of substance $\mathrm{P}$ by neurones and glial cells. Biochem Biophys Res Commun 125: 728-733.

Hunskaar S, Post C, Fasmer OB, Arwestrom E (1986) Intrathecal injection of capsaicin can be used as a behavioral nociceptive test in mice. Neuropharmacology 25:1149-1153.

Hylden JL, Wilcox GL (1981) Intrathecal SP elicits a caudally directed biting and scratching behavior in mice. Brain Res 271:212-215.

Igwe OJ, Felice LJ, Seybold VS, Larson AA (1988) Optimization of high-performance liquid chromatography-radioimmunoassay protocols for the analyses of substance $P$ and some of its metabolic fragments. J Chromatogr Biomed Appl 432:113-126.

Igwe OJ, Sun X, Larson AA (1990a) Correlation of substance P-induced desensitization with substance $P$ aminoterminal metabolites in the mouse spinal cord. Peptides 11:817-825.

Igwe OJ, Sun X, Larson AA (1990b) Role of substance P aminoterminal metabolites in substance $P$-induced descnsitization in micc. Neuroscience 36:535-542.

Jacques L, Couture R, Drapeau G, Regoli D (1989) Capillary permeability induced by intravenous neurokinins. Receptor characterization and mechanism of action. Naunyn Schmiedebergs Arch Pharmacol 340:170-179.

Johnson N, Pasternak GW (1984) Binding of tritium-labeled naloxonazine to rat brain membranes. Mol Pharmacol 26:477-483.

Kanagawa K, Minamino N, Fukuda A, Matsuo H (1983) Neuromedin $\mathrm{K}$ : a novel mammalian tachykinin identified in porcine spinal cord. Biochem Biophys Res Commun 114:533-540.

Kimura S, Okada M, Sugita Y, Kanagawa I, Munekata E (1983) Novel neuropeptides, neurokinin alpha and beta isolated from porcine spinal cord. Proc Jpn Acad Sci 59:101-104.

Kitabgi P, Carraway R, van Rietschoten J, Granier C, Morgat JL, Mcncz A, Leeman S, Freychet P (1977) Neurotensin: specific binding to synaptic membranes from rat brain. Proc Natl Acad Sci USA 74: $1846-1850$

Kosterlitz HW, Paterson SJ (1981) Tyr-D-Ala-Gly-MePhe$\mathrm{NH}\left(\mathrm{CH}_{2}\right)_{2} \mathrm{OH}$ is a selective ligand for the $\mu$-opiate binding site. $\mathrm{Br} \mathrm{J}$ Pharmacol 73:299.

Krumins SA, Kim DC, Seybold VS, Larson AA (1989) Modulation of $\left[{ }^{3} \mathrm{H}\right]$ DAMGO binding by substance $P(\mathrm{SP})$ and SP fragments in the mouse brain and spinal cord via $m_{i}$ interactions. Neuropeptides 13: 225-233.

Larson AA (1988) Desensitization to intrathecal substance P in mice: possible involvement of opioids. Pain 32:367-374.

Lasher R, Lutz E, Sanderson D (1986) Localization of endopeptidase 24.11 in the rat CNS at the light and electron microscopic level. Soc Neurosci Abstr 12:1045.

Lavielle S, Chassaing G, Ploux O, Loeuillet D, Bessyre J, Julien S, Marquet A, Convert O, Beaujouan J-C, Torrens Y, Bergstrom L, Saffroy M, Glowinski J (1988) Analysis of tachykinin binding site interactions using constrained analogues of tachykinins. Biochem Pharmacol 37:41-47.

Lee CM, Sandberg BEB, Hanley MR, Iversen LL (1981) Purification and characterization of a membrane bound substance P-degrading enzyme from human brain. Eur J Biochem 144:315-327.

Leysen JE, Gommeren W, Niemegeers CJE (1983) [ $\left.{ }^{3} \mathrm{H}\right]$-sufentanil, a superior ligand for $\mu$ opiate receptors: binding properties and regional distribution in rat brain and spinal cord. Eur J Pharmacol 87:209225

Mantyh PW, Hunt SP (1985) The autoradiographic localization of substance $P$ receptors in the rat and bovine spinal cord and the rat and cat trigeminal nucleus pars caudalis and the effects of neonatal capsaicin. Brain Res 332:315-324.

Matsas R, Kenny AJ, Turner AJ (1984) The metabolism of neuropeptides. The hydrolysis of peptides, including enkephalins, tachykinins, and their analogues, by endopeptidase-24.11. Biochem J 223 . $433-440$.

Mauborgne A, Bourgoin S, Benoliel JJ, Hirsch M, Berthier JL, Hamon M, Casselin F (1986) Enkephalinase is involved in the degradation of endogenous substance $P$ released from slices of rat substantia nigra. J Pharmacol Exp Ther 242:674-680.

McPherson GA (1983) A practical computer-based approach to the analysis of radioligand and binding experiments. Comput Programs Biomed 17:107-114.

Mosberg HI, Hurst R, Hruby VJ, Gee K, Yamamura HI, Galligan JJ, Burks TF (1983) Bis-penicillamine enkephalins possess highly improved specificity towards $\delta$ opioid receptors. Proc Natl Acad Sci USA 80:5871-5874.

Munson PJ, Rodbard D (1980) LIGAND: A versatile computerized approach for the characterization of ligand binding systems. Anal Biochem 107:220-239.

Nakata Y, Kusaka Y, Yajima H, Segawa T (1981) Active uptake of substance $P$ carboxy-terminal heptapeptide (5-11) into rat brain and rabbit spinal cord slices. J Neurochem 37:1 529-1534.

Naranjo JR, Arnedo A, DeFelipe MC, Del Rio J (1986) Antinociceptive and met-enkephalin releasing effects of tachykinins and substance $P$ fragments. Peptides 7:419-423.

Oblin A, Danse MJ, Zivkovic B (1989) Metallo-endopeptidase (EC 3.4.24.11) but not angiotensin converting enzyme is involved in the inactivation of substance $P$ by synaptic membranes of the substantia nigra. Life Sci 44:1467-1474.

Orloff MS, Turner AJ, Bunnett NW (1986) Catabolism of substance $P$ and neurotensin in the rat stomach wall is susceptible to inhibitors of angiotensin converting enzyme. Regul Peptides 14:21-31.

Park CH, Massari VJ, Quirion R, Tizabi Y, Shultz CW, O'Donohue TL (1984) Characteristics of ${ }^{3} \mathrm{H}$-substance $P$ binding sites in rat brain membranes. Peptides 5:833-836.

Pelleymounter MA, Fisher Q, Schlesinger K, Hall M, Dearmey P, Stewart JM (1986) The effect of substance $P$ and its fragments on passive avoidance retention and brain monoamine activity. Behav Brain Res 21:119-127.

Pernow B (1983) Substance P. Pharmacol Rev 35:85-141.

Piercey MF, Dobry P, Einspahr F, Schroeder L, Masiques N (1982) Use of substance $P$ fragments to differentiate substance $P$ receptors of different tissues. Regul Peptides 3:337-349.

Piercey MF, Dobry-Schreur PJK, Masiques N, Schroeder LA (1985) Stereospecificity of $\mathrm{SP}_{1}$ and $\mathrm{SP}_{2}$ substance $\mathrm{P}$ receptors. Life Sci 36: $777-780$.

Portoghese PS, Larson D, Sayre LM, Fries DS, Takemori AE (1980) A novel opioid receptor with irreversible narcotic antagonistic and reversible agonist activities. J Med Chem 23:233-234.

Probert L, Hanley MR (1987) The immunocytochemical localization of "substance P-degrading enzyme" within the rat spinal cord. Neurosci Lett 78:132-137.

Regoli D, Drapeau G, Dion S, Couture R (1988) New selective agonists for neurokinin receptors: pharmacological tools for receptor characterization. Trends Pharmacol Sci 9:290-295. 
Sakurada T, Greves P, Stewart J, Terenius L (1985) Measurement of substance $P$ metabolites in rat CNS. J Neurochem 44:718-722.

Sakurada T, Kuwahara H, Sakurada S, Kisara K, Ohba M, Munekata E (1987) Behavioral assessment of substance $P$ antagonists in mice. Neuropeptides 9:197-206.

Sakurada T, Kuwahara H, Takahashi K, Sakurada S, Kisara K, Terenius L (1988) Substance P (1-7) antagonizes substance P-induced aversive behavior in mice. Ncurosci Lett 95:281-285.

Segawa T, Nakata Y, Yajima H, Kitagawa K (1978) Further observation on the lack of active uptake system for substance $P$ in the central nervous system. Jpn J Pharmacol 27:573-580.

Simon EJ, Hiller JM, Edelman I (1973) Stereospecific binding of the potent narcotic analgesic $\left[{ }^{3} \mathrm{H}\right]$ etorphine in rat brain homogenate. Proc Natl Acad Sci USA 70:1947-1949.

Skilling S, Smullin D, Larson AA (1990) Differential effects of C- and $\mathrm{N}$-terminal substance $\mathbf{P}$ metabolites on the release of amino acid neurotransmitters from the spinal cord: potential role in nociception. J Neurosci 10:1309-1318.

Smith PK, Krohn RI, Hermanson GT, Mallia AK, Gartner FH, Provenzano MD, Fujimoto EK, Goeke NM, Olson BJ, Klenk DC (1985) Measurement of protein using bicinchroninic acid. Anal Biochem 150:76-85.

Stewart JM, Hall ME, Harkins J, Frederickson RCA, Terenius L, Hök- felt T, Krivoy WA (1982) A fragment of substance P with specific central activity: SP(1-7). Peptides 3:851-857.

Strittmatter SM, Thiele EA, Kapiloff MS, Snyder SH (1985) A rat brain isozyme of angiotensin-converting enzyme. Unique specificity for amidated peptide substrates. J Biol Chem 260:9825-9832.

Takahashi K, Sakurada T, Sakurada S, Kuwahara H, Yonezawa A, Ando R, Kigara K (1987) Behavioral characterization of substance P-induced nociceptive response in mice. Neuropharmacology 26:12891293.

Takemori AE, Larson DL, Portoghese PS (1981) The irreversible narcotic antagonist and reversible agonistic properties of the fumarate methyl ester derivative of naltrexone. Eur J Pharmacol 70:445-451.

Traczyk WZ, Kubicki J (1981) The pressor response of substance $\mathbf{P}$ and hexapeptide $\left[p \mathrm{Glu}^{6}\right] \mathrm{SP}(6-11)$ injections into the cerebral ventricles in rats. Neuropharmacology 19:607-611.

Tsou K, Wu S, Lu Y, Way EL (1985) Block of the hyoscine-resistant opiate withdrawal contracture of ileum by a new substance $P$ antagonist [D-Arg ${ }^{1}$, D-Phe ${ }^{5}$, D-Trp ${ }^{7.9}$, Leu ${ }^{11}$ ] substance P. Eur J Pharmacol 110:155-156.

Yokosawa H, Endo S, Ogura Y, Ishii S (1983) A new feature of angiotensin-converting enzyme in the brain: hydrolysis of substance $P$. Biochem Biophys Res Commun 116:735-742. 